\title{
Silindirle Sıkıştırılmış Beton (SSB) Kaplamaların Yüzey Özelliklerine Karışım Parametrelerinin Etkisi
}

\author{
Reza SHABANI \\ Emin ŞENGÜN² \\ Hande I. ÖZTÜRK ${ }^{3}$ \\ I. Özgür YAMAN ${ }^{4}$
}

ÖZ

Ülkemizde SSB kaplamaların şehir içi ve köy yollarında kullanımı gittikçe artmaktadır. Fakat yol sürüş konforunu ve güvenliğini etkileyen kaplama yüzey özelliklerine, karışım parametrelerinin etkisini inceleyen detaylı bir çalışma uluslararası literatürde mevcut değildir. Bu eksikliği gidermeye yönelik yapılan bu çalışmada, farklı çimento dozajları, agrega gradasyonları ve su oranları ile hazırlanan 12 SSB karışımı, "Superpave-YoğurmalıPresi” ile farklı seviyelerde sıkıştırılıp yüzey özellikleri, İngiliz pandülü ve kum yama testleriyle değerlendirilmiştir. Yapılan istatistiksel analizlerde, yoğurma sayısının etkisi görülmezken; SSB çimento dozajı, su muhtevası ve gradasyonun yalnızca mukavemet yönünden değil aynı zamanda yüzey özellikleri bakımından da etkili olduğu sonucuna varılmış ve SSB karışım optimizasyonu için öneriler getirilmiştir.

Anahtar Kelimeler: Silindirle sıkıştırılmış beton kaplamalar, yüzey özellikleri, kum yama testi, İngiliz pandül testi.

\section{ABSTRACT \\ The Effect of Mixture Parameters on the Surface Properties of Roller Compacted Concrete (RCC) Pavements}

In Turkey, the use of RCC pavements is increasing in urban and rural roads. However, a detailed study examining the effect of RCC mixture parameters on the pavement surface

\footnotetext{
Not: Bu yazı

- Yayın Kurulu'na 14 Mayıs 2020 günü ulaşmıştır. 9 Kasım 2020 günü yayımlanmak üzere kabul edilmiştir.

- 30 Kasım 2021 gününe kadar tartışmaya açıktır.

- https://doi.org/10.18400/tekderg.737322

1 Orta Doğu Teknik Üniversitesi, İnşaat Mühendisliği Bölümü, Ankara - rezashabani.1977@gmail.com https://orcid.org/0000-0002-9954-3261

2 Ankara Yıldırım Beyazıt Üniversitesi, İnşaat Mühendisliği Bölümü, Ankara - esengun@ybu.edu.tr https://orcid.org/0000-0001-7082-0061

3 Orta Doğu Teknik Üniversitesi, İnşaat Mühendisliği Bölümü, Ankara - ozturkha@metu.edu.tr https://orcid.org/0000-0003-1597-5348

4 Orta Doğu Teknik Üniversitesi, İnşaat Mühendisliği Bölümü, Ankara - ioyaman@metu.edu.tr https://orcid.org/0000-0001-6489-6852
} 
properties that affect road driving comfort and safety is not available in literature. In this study, in order to cover that gap in literature 12 RCC mixtures prepared with different cement dosages, aggregate gradations and water amounts were compacted by "Superpave-GyratoryCompactor" at different levels. Later, the surface characteristics were evaluated with British pendulum and sand patch tests. It was concluded that cement dosage, water content and gradation have an effect not only in terms of strength but also in terms of pavement surface properties, and recommendations were made for RCC mixture optimization.

Keywords: Roller compacted concrete pavements, surface properties, sand patch test, British pendulum test.

\section{GíRiș}

Şehir içi ve köy yollarında artan ağır trafik yükleri ve bakım onarım maliyetlerinin gittikçe yükselmesi ülkemizde belediyelerin ve il özel idarelerinin asfalt ve sathi kaplamalar yerine daha ekonomik ve uzun ömürlü yeni alternatifler aramasına neden olmuştur. $\mathrm{Bu}$ alternatiflerden biri de Silindirle Sıkıştırılmış Beton (SSB) kaplamalardır. Başta Amerika Birleşik Devletleri olmak üzere birçok ülkede SSB kaplamalar, özellikle ağır yüklere maruz kalan ve düşük trafik hızında işletilen endüstriyel tesisler, limanlar ve park alanlarında tercih edilmektedir. SSB kaplamaların başlıca üstünlükleri yüksek mukavemete ve dayanaklılığa sahip olması ve geleneksel asfalt kaplama ekipmanları (vibrasyonlu çelik silindirler) ile üretilebilmesidir [1]. Buna ek olarak geleneksel beton karışımlarına kıyasla kuru kıvamda olması, SSB kaplamaların trafiğe çok hızlı bir şekilde açılabilmesine olanak vermektedir. SSB kaplamaların bu özellikleri ülkemiz için bu uygulamayı önemli bir alternatif haline getirmiştir. Fakat literatürde belirtildiği üzere SSB kaplamalarının yüzey dokusu ve yüzey düzgünsüzlüğü ile ilgili problemleri yüksek hızlı yollarda kullanımında tercih edilmemesine sebep olmaktadır.

Ülkemizde son yıllarda giderek yaygınlaşan SSB kaplama uygulamaları 1000 km yi aşmakta ve başta Karadeniz, Marmara ve İç Anadolu Bölgelerimiz olmak üzere 37 ilde başarıyla uygulanmaktadır. Fakat ülkemizde şehir içlerinde ve köy yollarında gelişen araç teknolojileri ve denetim eksikliği nedeniyle artan trafik hızları, yol üstyapısı yüzey dokusu ile araç frenleme mesafesi arasındaki etkileşimin daha detaylı bir şekilde incelenmesini gerektirmektedir. Bu sebeple ülkemizde kullanımı hızla artan SSB kaplamalarının yüzey doku özelliklerinin incelenmesi gerekmektedir (Bkz. Şekil 1). Kaplamaların mikro ve makro dokusu sürtünme direncini etkilediğinden yol güvenliği için büyük önem arz etmektedir. Mikro doku $(<0,5 \mathrm{~mm})$, karışımdaki agregaların yüzey özelliğine bağlıdır ve kaplama ile tekerlek arasındaki su filminin parçalanmasını ve lastikle yol arasında kuru teması sağlar. Bu da özellikle düşük hızlarda sürtünme direncinin sağlanmasında oldukça etkili olmaktadır. Diğer taraftan, maksimum agrega dane boyutuna, karışımın gradasyonuna ve agrega dağılımına bağlı olan makro doku ise $(0,5 \mathrm{~mm}-50 \mathrm{~mm})$ yüksek hızlarda kaplama yüzeyinin drenaj kapasitesine etki etmektedir.

$\mathrm{Bu}$ çalışma kapsamında, SSB karışım özelliklerinin hem makro hem de mikro doku özelliklerini nasıl etkilediğinin araştırılması hedeflenmiştir. Bu amaçla, iki farklı çimento dozajı $\left(200\right.$ ve $\left.400 \mathrm{~kg} / \mathrm{m}^{3}\right)$, iki farklı maksimum agrega dane boyutu (12 ve $19 \mathrm{~mm}$ ) ve üç farklı miktarda su içeriği (\%4, \%5 ve \%6) ihtiva eden toplamda 12 farklı karışım, Superpave Yoğurmalı Presi (SYP) kullanılarak üç farklı yoğurma sayısı (50, 60 ve 75) kullanılarak 
sıkıştırılmış̧ır. Hazırlanan numunelerin sürtünme ve mikro doku özelliklerinin değerlendirilmesi için İngiliz pandülü testi (BPT) ve makro doku değerlendirilmesi için kum yama testi, literatürde en yaygın kullanılan basit yöntemler oldukları için tercih edilmiştir.

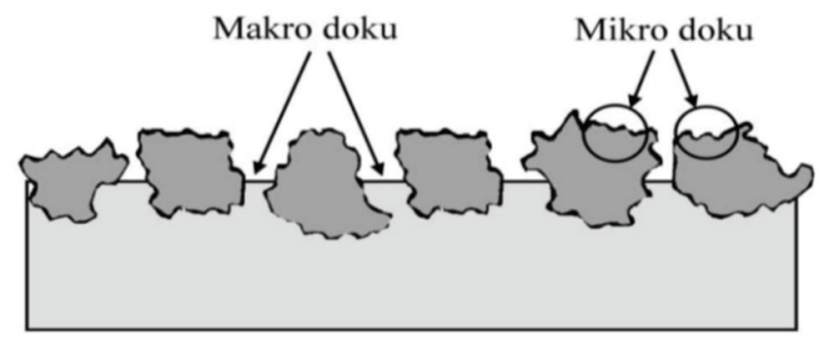

Şekil 1 - Yol kaplama yüzeyi makro ve mikro doku [2].

\section{LITERATÜR TARAMASI}

Esnek ve rijit kaplamaların yüzey özelliklerini araştıran birçok yayın olmasına rağmen, SSB kaplamaların yüzey özelliklerini çalışan oldukça az sayıda makale literatürde mevcuttur. Bunlardan birinde Chhorn vd. (2017), beş farklı SSB yol kesitinde sürtünme özelliklerini incelemiş̧ir [3]. 13 ve $19 \mathrm{~mm}$ maksimum dane boyutuna sahip SSB kaplamaların mikro doku özellikleri ile Vebe süreleri arasında ilişki kurmuştur. Kuru SSB karışımlarda harç miktarı yetersiz kaldığı için sıkıştırmadan sonra agrega dokusunun açığa çıkmasına neden olabileceği gözlemlenmiştir. Bunun nedeni olarak da harcın yüzey alanını kaplamada yetersiz kaldığı belirtilmiştir. Diğer yandan sslak SSB karışımlarında ise yeterli miktarda harç yüzey alanındaki agregalar arasındaki boşlukları kaplamasından ötürü kaymaya ve dolayısıyla düşük sürtünme direncine neden olabileceği sonucuna varılmıştır. Yapılan deneysel çalışmada optimum Vebe süresi 55 sn olarak bulunmuş ve maksimum dane boyutu $19 \mathrm{~mm}$ olan SSB karışımları, $13 \mathrm{~mm}$ olana kıyasla biraz daha yüksek ölçülmüştür. Diğer güncel bir çalışmada ise nano-silika katkısının atık lastik ihtiva eden beton ile üretilen SSB karışımları üzerine etkisini çalışılmıştır [4]. Her ne kadar esas amaç bu bileşenlerin SSB'nin mekanik özelliklerine etkisi olsa da yüzey özelliklerine ilişkin bir değerlendirme de yapılmış ve İngiliz pandül sayısı (BPN) değerinin atık lastiğin ince agreganın \%20'sine kadar kullanımıyla arttığ gözlemlenmiştir. Yapılan ölçümlerde kuru koşuldaki BPN değeri, sslak koşullardan daha yüksek elde edilmiştir. Bunun sebebi sslak kaplamaların daha kaygan yüzey dokusu üretmesi ve böylece kayma direncini azaltmasıdır. $\mathrm{Bu}$ çalışmada ayrıca nano-silika $\left(\mathrm{SiO}_{2}\right)^{\prime}$ 'nı kayma direncine pozitif etkisi olduğu görülmüştür. Başka bir çalışmada ise seramik, cam ve beton atıklarının SSB' lerde agrega olarak kullanılması araştırılmıştır [5]. Aynı çalışmada atıkların karışımlar üzerinde doğurabileceği olumsuz etkileri ortadan kaldırmak için nano-silika karışımlara ilave edilmiş̧ir. Nano-silika ilave edilmeyen farklı karışımlarda mikro doku 33 ile 42 arasında değişirken, nano-silika ilave edilen karışımların sürtünme dayanımında \%3-6 arası artış gözlemlenmiştir. Diğer bir çalışmada ise Algin ve Gerginci (2020) [6], donma çözülme döngüsüne maruz kalan sentetik fiber katkılı SSB kaplamaların kayma direnci dayanımını incelemiştir. Araştırmacılar, her 100 donma çözülme döngüsü sonrasında ölçüm alarak toplamda dörder kez hem kuru hem de sslak şartlar altında kayma direnci dayanımı ölçmüşlerdir. Donma çözülme döngüleri öncesinde tüm 
numunelerde benzer BPN değerleri ölçülürken, 300 döngü sonrası kontrol numunesinde (fiber katılmamış) diğer numunelerden daha hızlı BPN değeri düşmüştür. Kuru olarak test edilen numunelerin tamamında BPN değerleri 54’ten büyük ölçülmüştür. Bu sebeple SSB kaplamaların hem donma çözülme döngüsü öncesi hem sonrasında çok düşük kayma potansiyeli olduğu sonucuna varılmıştır. Islak yapılan deneylerde ise BPN değerleri biraz daha düşük bulunmuş ve bu nedenle düşük kayma potansiyeline sahip kaplama olarak sınıflandırılmış ve fiber katkısının yüzey aşınmasına olumlu katkısı olduğu sonucuna varılmıştır. Bu çalışmalarının dışında ayrıca ACI 325.10R-95 raporunda [7], yüksek hızlı araç ve havaalanı trafikleri için ASTM E670 [8] yöntemine uygun olarak Amerika ve Avustralya daki birçok yerde yapılan ölçümler de özetlenmiştir. Bu ölçümler Amerikan hava kuvvetleri kriterlerine göre değerlendirildiğinde sürtünme sınırda veya düşük olarak sınıflandırılmıştır.

Yukarıdaki literatür özetinden de görüleceği üzere SSB karışım tasarımında kullanılan parametrelerin (çimento dozajı, su muhtevası ve agrega dane boyutu büyüklüğü) hem makro hem de mikro doku özelliklerini nasıl etkilediği detaylı bir şekilde araştırılmamıştır.

\section{MATERYAL VE METOT}

\subsection{Malzeme Seçimi ve Karışım Tasarımı}

Tüm SSB karışımlarının hazırlanmasında TS EN 197-1 standardına göre üretilen CEM I 42,5 R tipi standart Portland çimentosu ve kırma kireçtaşı agregası kullanılmıştır. Çalışmada literatürde yapılan farklı bağlayıcı oranlarındaki SSB çalışmalarını da kapsaması açısından geniş bir çimento miktar aralığı hedeflenerek $200 \mathrm{ve} 400 \mathrm{~kg} / \mathrm{m}^{3}$ olmak üzere iki farklı çimento dozajı seçilmiştir. Burada; $200 \mathrm{~kg} / \mathrm{m}^{3}$ dozajlı karışımlar düşük dozajlı normal dayanımlı SSB karışımlarını temsil ederken, $400 \mathrm{~kg} / \mathrm{m}^{3}$ karışımlar ise yüksek performanslı SSB karışımların elde edilmesi için tercih edilmiştir. Çalışmada kullanılan üç farklı agrega boyutu (ince agrega 0-5 mm, iri agrega 5-12 $\mathrm{mm}$ ve iri agrega 12-19 mm) için agrega harmanlarının dane büyüklüğü dağılımı Şekil 2'de verilmiştir $[9,10]$.

Agregalara ait fiziksel özellikleri incelendiğinde iri ve ince agregalara ait kuru yüzey doygun haldeki özgül ağırlıkları ile su emme oranları sırasıyla 12-19 mm boyutlarındaki iri agrega için 2,71 ve $\% 0,18,5-12 \mathrm{~mm}$ boyutlarındaki iri agrega için 2,69 ve $\% 0,29,0-5 \mathrm{~mm}$ boyutlarındaki kırma kum ince agrega için ise 2,67 ve \%1,24 olarak elde edilmiştir [11, 12$]$. Ayrıca ince agrega için incelik modülü ise 3,2 olarak bulunmuştur [13].

Karışımın agrega gradasyonu belirlenirken, Amerika Beton Yol Birliği (ACPA) [14] tarafından tavsiye edilen SSB kaplama agrega gradasyonlarına ait alt ve üst limitler ile Karayolları Genel Müdürlüğü (KGM) [15] tarafından bitümlü sıcak karışım (BSK) uygulamaları için önerilen agrega gradasyonuna ait alt ve üst limitler de göz önüne alınmıştır. Şekil 3 te sunulduğu üzere her iki gradasyon limiti de birbirine çok yakındır ve bunun başlıca sebeplerinden biri de hem asfalt hem de SSB kaplamaların aynı ekipmanlar ve benzer prosedürler ile serilmesi ve sıkıştırılmasıdır. Bu sebeple belirtilen alt ve üst limitler içinde kalarak maksimum agrega dane boyutu ( $\left.\mathrm{D}_{\text {maks }}\right) 12 \mathrm{~mm}$ için \%65 (0-5 mm), \%35 (5-12 mm), $\% 0$ (12-19 mm); $\mathrm{D}_{\text {maks }} 19 \mathrm{~mm}$ için \%50 (0-5 mm), \%40 (5-12 mm), \%10 (12-19 mm) olarak belirlenmiş ve gradasyon eğrileri Şekil 3 'te verilmiştir. 


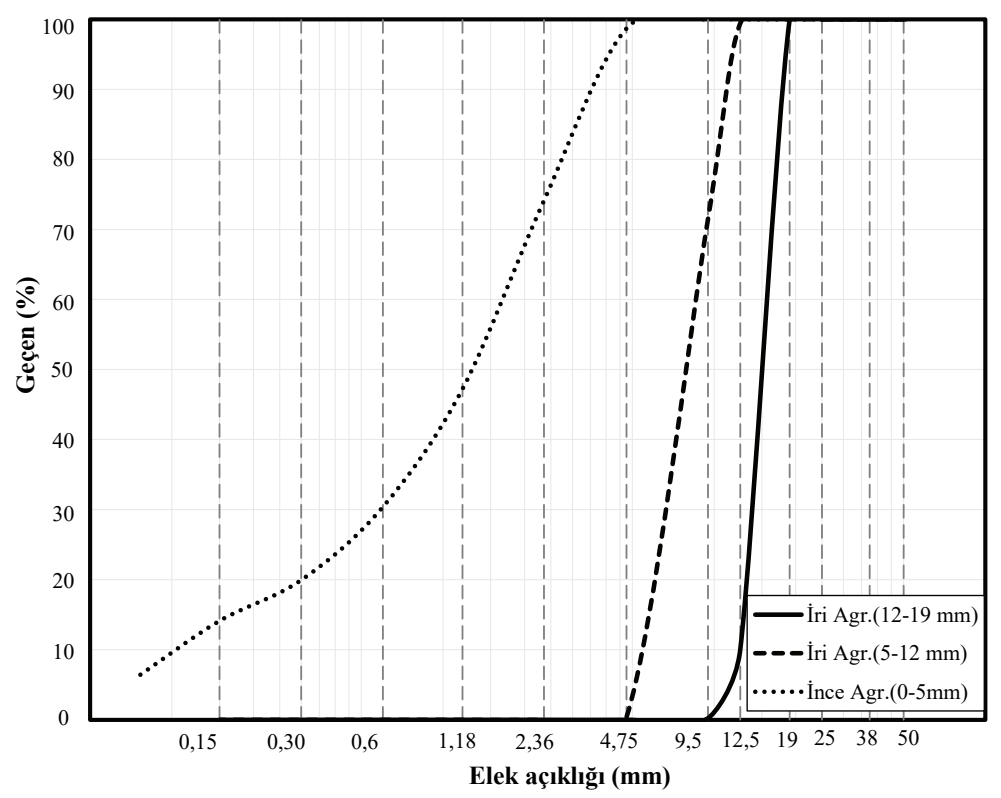

Şekil 2 - Ince ve iri agrega tane büyüklüğü dă̆ılımı

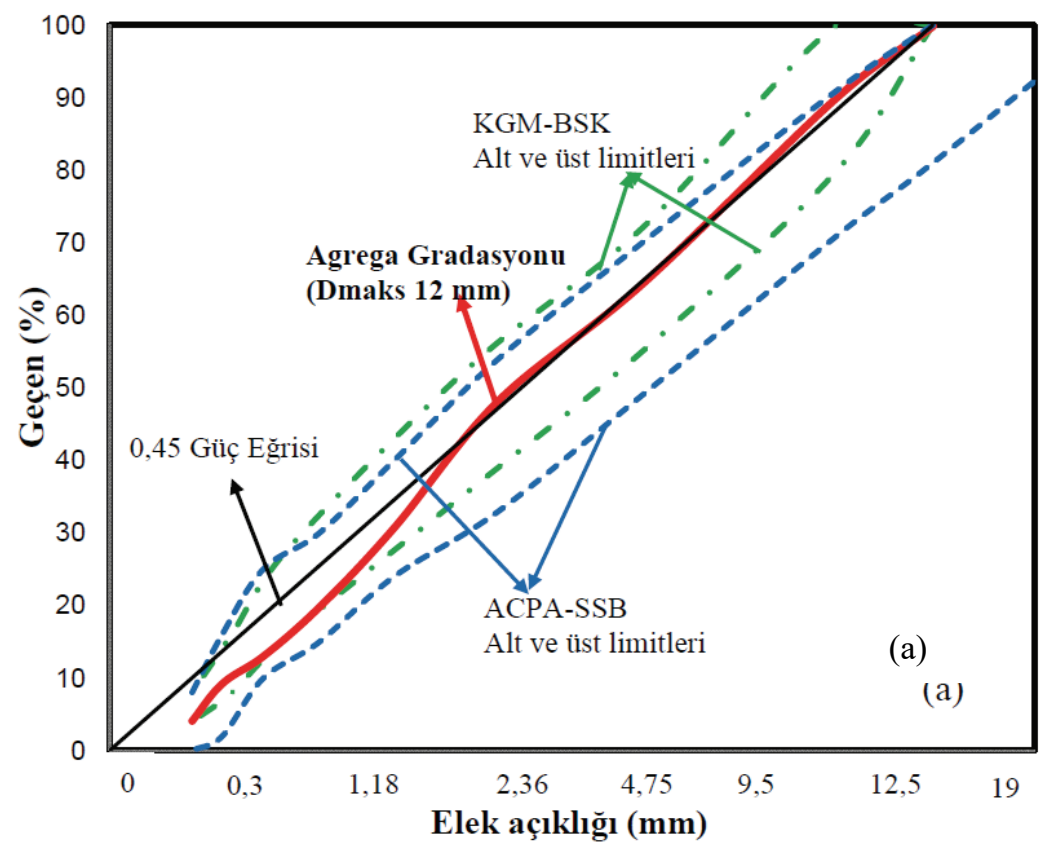

Şekil 3 - SSB karışım tasarımında kullanılan agrega gradasyonları (a) $D_{\text {maks }} 12 \mathrm{~mm}$ (b) $D_{\text {maks }} 19 \mathrm{~mm}$. 


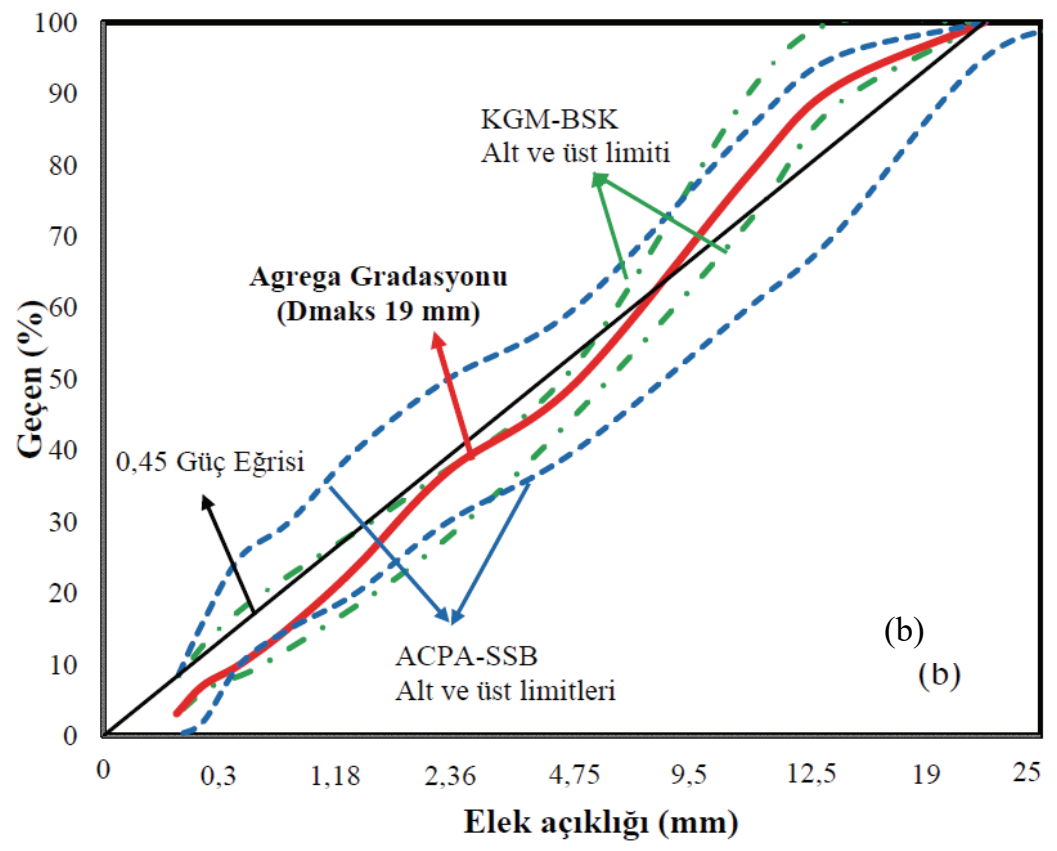

Şekil 3 - SSB karışım tasarımında kullanılan agrega gradasyonları (a) $D_{\text {maks }} 12 \mathrm{~mm}$ (b) Daks $19 \mathrm{~mm}$. (devam)

Çalışma kapsamında, iki farklı agrega gradasyonu ( $D_{\text {maks }} 12$ ve $19 \mathrm{~mm}$ ) ve iki farklı çimento dozajının (200 ve $400 \mathrm{~kg} / \mathrm{m}^{3}$ ) yanı sıra agrega ve çimento toplam ağırlığının \%4, \%5 ve \%6'sı olmak üzere üç farklı su oranı kullanılarak toplamda 12 karışım incelenmiştir. Karışımlara ait tasarım Tablo 1'de verilmiştir. Burada kullanılan su oranı, su miktarının bağlayıcı malzeme ve agrega miktarına oranı; s/ç, su miktarının bağlayıcı miktarına oranı; C, bağlayıcı malzeme miktarının bağlayıcı malzeme ve agrega miktarına oranı ve İA/TA ise ince agrega miktarının toplam agrega miktarına oranı olarak tanımlanmıştır.

Karışım tasarımı yapılırken ABD Beton Yol Teknoloji Merkezi [1] tarafından hazırlanan SSB yol kaplamaları kılavuzuna uyumlu olarak beton karışım oranlaması \%2'lik hava boşluğu varsayımı ile klasik ağırlık/hacim hesaplaması ile gerçekleştirilmiştir. Tablo 1'de verildiği üzere karışımlar; çimento dozajı (C200 veya C400)- maksimum agrega dane boyutu (D12 veya D19) - su oranı (W4, W5 veya W6) kullanılarak adlandırılmıştır.

Tablo 1'den görüleceği üzere $200 \mathrm{doz}$ çimentolu karışımların s/ç oranları 0,48 ile 0,69 arasında, 400 doz çimentolu karışımların s/ç oranları ise 0,24 ile 0,35 arasında değişmektedir. Bağlayıcı malzeme miktarı ise ağırlıkça \%8,4 ile \%18,9 arasında değişmektedir. Her karışım sonrasında SSB kıvamın belirlenmesi için Vebe testi (ASTM C1170) [16] 22,7 kg'lık ilave yük ile daha kuru, oldukça katı kıvamlı SSB'ler için önerilen prosedür A kullanılarak gerçekleştirilmiştir. 
Tablo 1 - SSB karışım tasarımı $\left(1 \mathrm{~m}^{3}\right.$ için $)$

\begin{tabular}{|c|c|c|c|c|c|c|c|c|c|c|c|}
\hline No & Karışım No. & $\begin{array}{c}\text { Çimento } \\
\text { Dozaj1 } \\
\text { (kg) }\end{array}$ & $\begin{array}{c}\text { Maks. } \\
\text { Agrega } \\
\text { Boyutu } \\
(\mathrm{mm})\end{array}$ & $\begin{array}{l}\mathrm{Su} \\
\text { Oran1 } \\
(\%)\end{array}$ & $\begin{array}{c}\mathrm{Su} \\
\text { Miktar1 } \\
(\mathrm{kg})\end{array}$ & $\begin{array}{c}\text { İnce } \\
\text { Agrega } \\
(0-5 \\
\mathrm{mm}) \\
(\mathrm{kg})\end{array}$ & $\begin{array}{c}\text { İi } \\
\text { Agrega } \\
(5-12 \\
\mathrm{mm}) \\
(\mathrm{kg})\end{array}$ & $\begin{array}{c}\text { İri } \\
\text { Agrega } \\
(12-19 \\
\mathrm{mm}) \\
(\mathrm{kg})\end{array}$ & $\mathrm{s} / \mathrm{ç}$ & $\mathrm{C}(\%)$ & İA/TA \\
\hline 1 & C200-D12-W4 & 200 & 12 & 4 & 96 & 1424 & 770 & - & 0,48 & 8,35 & 0,65 \\
\hline 2 & C200-D12-W5 & 200 & 12 & 5 & 117 & 1388 & 750 & - & 0,59 & 8,55 & 0,65 \\
\hline 3 & C200-D12-W6 & 200 & 12 & 6 & 137 & 1353 & 731 & - & 0,69 & 8,76 & 0,65 \\
\hline 4 & C200-D19-W4 & 200 & 19 & 4 & 96 & 1095 & 880 & 222 & 0,48 & 9,20 & 0,50 \\
\hline 5 & C200-D19-W5 & 200 & 19 & 5 & 117 & 1067 & 857 & 216 & 0,59 & 9,42 & 0,50 \\
\hline 6 & C200-D19-W6 & 200 & 19 & 6 & 137 & 1040 & 835 & 211 & 0,69 & 9,64 & 0,50 \\
\hline 7 & C400-D12-W4 & 400 & 12 & 4 & 97 & 1312 & 709 & - & 0,24 & 16,52 & 0,65 \\
\hline 8 & C400-D12-W5 & 400 & 12 & 5 & 118 & 1275 & 689 & - & 0,30 & 16,92 & 0,65 \\
\hline 9 & C400-D12-W6 & 400 & 12 & 6 & 139 & 1240 & 670 & - & 0,35 & 17,32 & 0,65 \\
\hline 10 & C400-D19-W4 & 400 & 19 & 4 & 97 & 1009 & 810 & 205 & 0,24 & 18,03 & 0,50 \\
\hline 11 & C400-D19-W5 & 400 & 19 & 5 & 118 & 981 & 788 & 199 & 0,30 & 18,44 & 0,50 \\
\hline 12 & C400-D19-W6 & 400 & 19 & 6 & 139 & 953 & 766 & 194 & 0,35 & 18,88 & 0,50 \\
\hline
\end{tabular}

Not: Karışım isimleri çimento dozajı (C), Dmaks büyüklüğü ve su oranı (w) ile etiketlenmiştir.

\subsection{Numunelerin Üretilmesi}

Tablo 1'de belirtilen SSB karışımlarının hazırlanmasının ardından çalışmada özellikle saha sıkıştırma koşullarını laboratuvar ortamında en yakın şekilde temsil edebilmesi açısından SYP kullanılmıştır [17]. SYP, uzun yıllardır asfalt karışım tasarımı için sahadaki sıkıştırma şartlarını daha iyi temsil ettiği için tercih edilen bir yöntemdir. Başka bir deyişle diğer laboratuvar yöntemlerinin aksine (darbe ile sıkıştırma) kalıbın boylamsal ekseni etrafında yoğurularak döndürülmesi sonucu sıkıştııılmasından dolayı saha koşullarını laboratuvar ortamında temsil etmektedir (Şekil 4). Ayrıca, SYP'lerin en önemli avantajı farklı yoğurma sayıları ile numunelerin istenilen yoğunluğa ve sıkıştırma derecesine ulaşabilmesini sağlamasıdır.
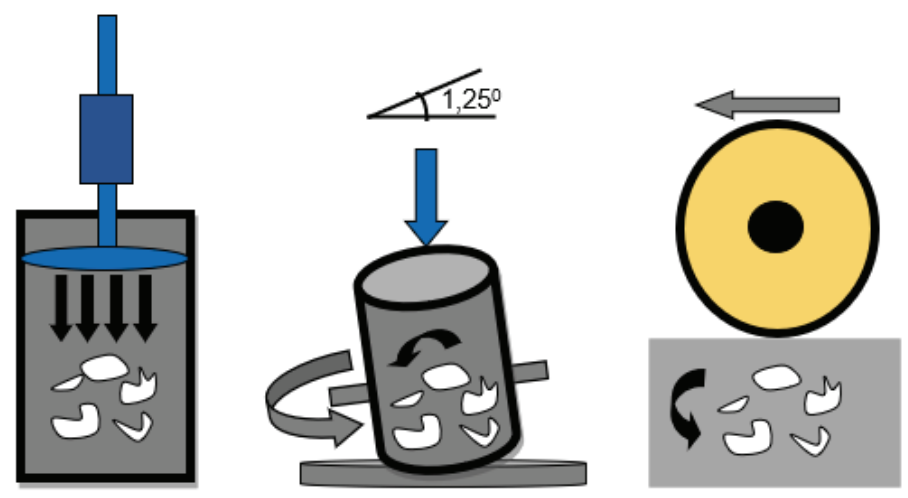

Şekil 4 - Darbeli, yoğurmalı ve silindir sıkıştırıcıların tipik sılkş̧tırma mekanizmaları 
Ancak SSB'lerin SYP ile üretilmesi üzerine özellikle Amerikan Test ve Malzeme Birliği (ASTM) tarafından yeni çalışmalar devam etmekle birlikte halihazırda bir standart (ASTM C1800) [18] bulunmakta olup, bu standartta da SSB'ler için istenilen yoğunluğa gelmesi için 50-60 yoğurma sayısı tavsiye edilmektedir. Fakat nihai karar araştırmacıya bırakılmaktadır. $\mathrm{Bu}$ çalışmada da farklı yoğurma sayılarının yüzey özellikleri üzerindeki etkisinin de görülebilmesi adına her bir SSB karışımından 50, 60 ve 75 yoğurma sayılarında 3'er adet ayrı ayrı numuneler üretilmiştir. SYP ile üretilen SSB numunelerin bir kısmı Şekil 5'te görülmektedir. Üretilen numunelere 28 güne kadar sslak bezle kür uygulanmıştır.

\subsection{Yüzey Özelliklerinin Belirlenmesi}

Bu çalışma kapsamında SSB'lerin yüzey özelliklerinin belirlenebilmesi adına makro yüzey dokusu için kum yama testi (sand patch test) ve mikro yüzey dokusu içinse İngiliz pandülü testi (British pendulum test) kullanılmıştır. Her iki yöntem de hem literatürde hem de uygulamada çok sık tercih edilmesine rağmen, sadece düşük hızlar için yol güvenliğinin ölçülmesine yardımcı olmaktadır.
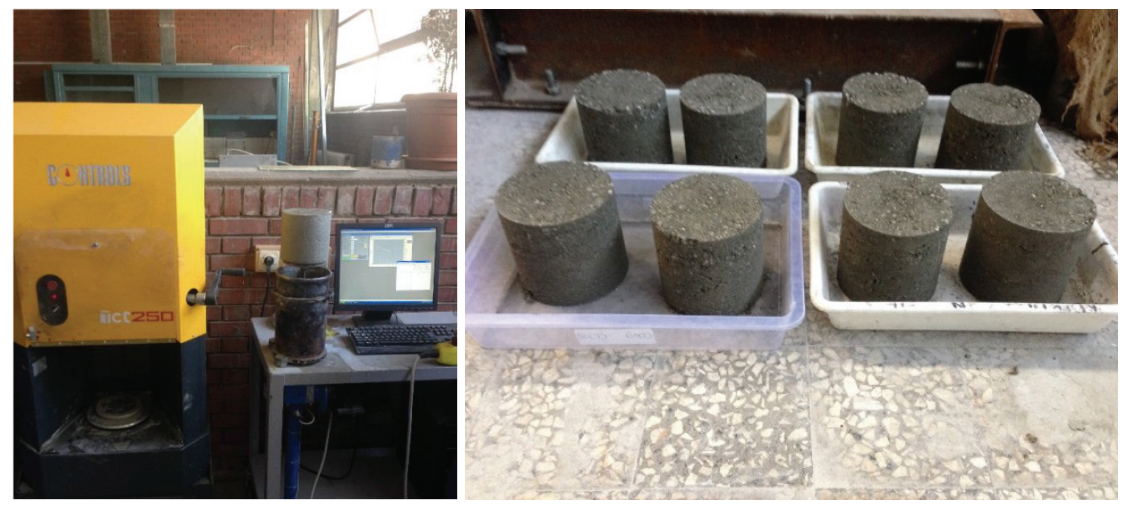

Şekil 5 - SYP ile SSB numunelerin üretimi

\subsubsection{Kum Yama Testi}

$\mathrm{Bu}$ çalışmada, yol yüzey makro doku derinliğinin belirlenmesi için özellikle kolay uygulanabilir olması nedeniyle tüm dünyada oldukça sık kullanılan yöntemlerden biri olan kum yama testi tercih edilmiştir. ASTM E965 [19] prosedürüne uygun olarak yapılan deneylerde, temiz ve kuru kaplama yüzeylerinin üzerine hacmi bilinen \%90 yuvarlaklığa sahip cam bilyaların dikkatli bir şekilde yuvarlak bir disk yardımıyla dağıtılması sonucunda kapladığı toplam alanın ölçülmesi ile yol yüzeyinin ortalama doku derinliği (MTD) hesaplanmaktadır. Bu amaçla standart boyutlarda (en az \% 90'1 No.60 elek açıklığından geçip No.80 üzerinde kalan gradasyona sahip) ve hacmi bilinen bir miktar cam bilya kaplama girintilerini dolduracak şekilde yüzeye dairesel olarak yayılmakta ve ardından dairenin ortalama çapı ile cam bilyanın hacmi kullanılarak MTD hesaplanmaktadır [20]. Türkiye Beton Yol Kaplamaları Teknik Şartnamesine göre MTD değeri beton yollar için 0,6 mm ile 
1,1 mm arasında olması beklenmektedir [21]. Bu çalışmada, her bir karışım için üçer numune üzerinde kum yama testi gerçekleştirilmiştir (Şekil 6).

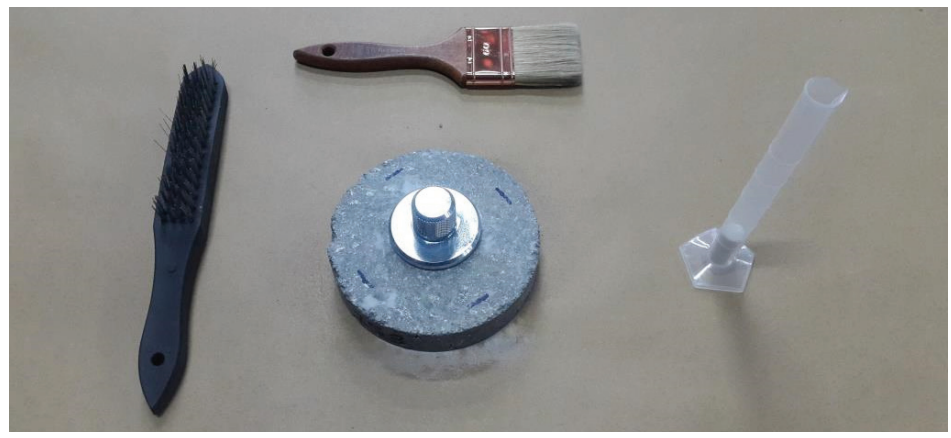

Şekil 6 - SSB numuneleri üzerinde kum yama testi malzemeleri

\subsubsection{Ingiliz Pandülü Testi (BPT)}

BPT kuru veya sslak düz yüzeylerde kayma direncini kolayca belirlemek için hem sahada hem de laboratuvar da oldukça sık tercih edilen bir yöntemdir (Şekil 7a). Bu yöntemde sarkaca monte edilmiş kauçuk sürtünme parçasının yüzey üzerinden itilirken enerji kaybı ölçülerek, yüzeyin sürtünme özellikleri belirlenir. ASTM E303 [22] yöntemine uygun olarak, deney öncesinde numune yüzeylerinin temizlenmesi ve BPT deney düzeneğinin her numuneden önce ayarlanması gerekmektedir.

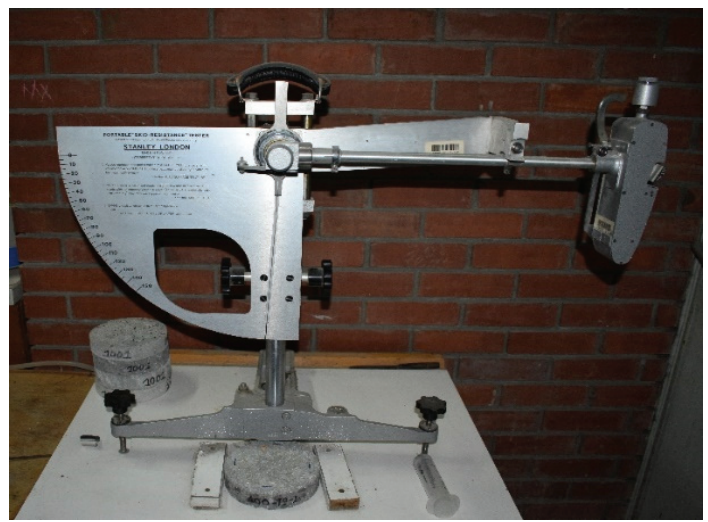

(a)

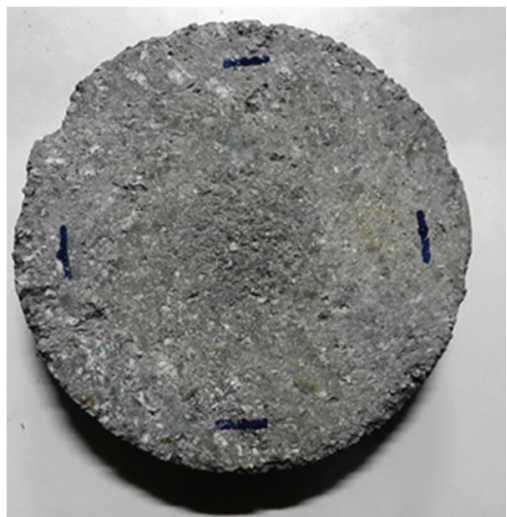

(b)

Şekil 7 - a) Ingiliz pandül test ile SSB numuneleri üzerinden ölçüm alınması, b) işaretli numune

Bu çalışma kapsamındaki numuneler SYP ile hazırlandığından üretilen 152,4 mm çapında dairesel numuneler üzerinde BPT hem kuru hem de sslak koşullarda uygulanmıştır. Bunun amacı SSB'nin sürtünme özelliklerinin ıslak hava şartlarında nasıl değiştiğini görebilmektir. 
Her numunenin üzerinde $1,5 \mathrm{~cm}$ numune kenarının içinden birbirine $90^{\circ}$ açılı 4 nokta seçilerek ölçüm her noktadan dörder kez alınarak ortalama BPN değerleri hesaplanmıştır (Şekil 7b). Islak yüzey üzerinde yapılan deneyler için ASTM E303 [22], yüzeyin yeterince 1slatılması gerektiğini söylese de bunu detaylıca tanımlamamıştır. Aynı zamanda literatürdeki çalışmalarda da herhangi bir prosedür detayı verilmemiştir. Bu sebeple $150 \mathrm{~mm}$ çapındaki numuneleri yeterince ıslatmak için gerekli su miktarının belirlenmesi için bir ön çalışma yapılmıştır. Ön çalışmalar neticesinde tüm numuneler için $50 \mathrm{ml}$ suyun yeterli olduğu tespit edilmiş ve numunenin yüzeyinde ince bir film tabakası oluşması sağlanmıştır. Standartta belirtildiği üzere her bir ölçümden önce tekrar numunenin üst yüzeyi sslatılarak tekrarlanmıştır.

Yıldız (2018) çalışmasında yer alan BPN değerine göre kayma sınıflandırması Tablo 2'de yer almaktadır.

Tablo 2 - BPN dĕgerlerine göre kayma sınıflandırması [23]

\begin{tabular}{ccccc}
\hline Sınıflama & $\begin{array}{c}\text { Kayma } \\
\text { potansiyeli }\end{array}$ & $\begin{array}{c}\text { Kayma } \\
\text { olasılığı }\end{array}$ & Cof & BPN \\
\hline Z & Çok yüksek & $1 / 20$ & $<0,25$ & $<24$ \\
Y & Yüksek & $1 / 200$ & $0,25-0,34$ & $25-34$ \\
X & Orta & $1 / 10.000$ & $0,36-0,46$ & $35-44$ \\
W & Düşük & $1 / 100.000$ & $0,47-0,59$ & $45-54$ \\
V & Çok Düşük & $1 / 1$ milyon & $>0,59$ & $>54$ \\
\hline
\end{tabular}

\section{ANALIZLER VE BULGULAR}

SSB karışımlarına ait MTD ile hem kuru hem ıslak BPN değerleri Tablo 3'te ve Şekil 8'de verilmiştir. Sonuçlar üçer adet numune ortalamasından oluşmaktadır. Ayrıca Şengün vd. (2019) tarafından yapılan bir önceki çalışmadan elde edilen Vebe kıvam süreleri ve 28 günlük basınç dayanımları da yüzey özellikleri ile ilişkilerinin incelenmesi için ilgili tabloda sunulmuştur [17].

Tablo 3'te görüldüğü üzere 200 dozajlı karışımlar için yüzey derinliği ortalama $0,46 \mathrm{~mm}$ iken, 400 dozajlı karışımlarda agrega boyutuna da bağlı olarak $D_{\text {maks }}-12 \mathrm{~mm}$ için $0,32 \mathrm{~mm}$, $\mathrm{D}_{\text {maks-19 }} 19 \mathrm{~mm}$ için 0,25 mm elde edilmiştir. Bu sonuçlar 1şı̆̆ında 200 dozajlı karışımlarda MTD değeri Karayolları Beton Yolları Teknik Şartnamesi [21] değerlerini sınırdan sağlarken, 400 dozajlı karışımların MTD değeri ise çok düşük ölçülmüştür.

Diğer taraftan mikro doku yüzey özelliklerine bakıldığında Şekil 8'den de görüldüğü üzere beklendiği gibi ıslak BPN değerleri, kuru BPN değerlerine göre daha düşüktür. Tüm SSB karışımlar için ortalama değerlere bakıldığında, BPN kuru yüzeyde 70, 1slak yüzeyde ise 200 dozaj için 64, 400 dozaj için 62 civarında olduğunu gözlemlenmiştir. Bu BPN değerleri de Tablo 2'deki kayma sınıflandırması değerleri ile karşılaştırıldığında SSB kaplamalar "V sınıfı" ile "çok düşük kayma" potansiyeline sahip kaplama sınıfına girdiği görülmektedir. 
Tablo 3 - SSB karlşımlarına ait makro ve mikro yüzey özellik değerleri

\begin{tabular}{|c|c|c|c|c|c|c|c|c|}
\hline $\begin{array}{l}\text { Çimento } \\
\text { Miktarı } \\
\left(\mathrm{kg} / \mathrm{m}^{3}\right)\end{array}$ & $\mathrm{D}_{\text {maks }}(\mathrm{mm})$ & Su oranı $(\%)$ & $\begin{array}{c}\text { Vebe Süresi } \\
\text { (sn) }\end{array}$ & Yoğurma Sayısı & $\begin{array}{l}\text { Basınç } \\
\text { Dayanımı } \\
(\mathrm{MPa})\end{array}$ & $\begin{array}{l}\text { MTD } \\
(\mathrm{mm})\end{array}$ & $\begin{array}{l}\text { BPN } \\
\text { Kuru } \\
\text { yüzey }\end{array}$ & $\begin{array}{r}\text { BPN } \\
\text { Islak } \\
\text { yüzey }\end{array}$ \\
\hline \multirow{20}{*}{200} & \multirow{9}{*}{12} & \multirow{3}{*}{4} & \multirow{3}{*}{55} & 50 & 21,9 & 0,50 & 73 & 64 \\
\hline & & & & 60 & 23,4 & 0,49 & 71 & 65 \\
\hline & & & & 75 & 27,6 & 0,47 & 71 & 71 \\
\hline & & \multirow{3}{*}{5} & \multirow{3}{*}{32} & 50 & 20,0 & 0,51 & 71 & 66 \\
\hline & & & & 60 & 22,7 & 0,52 & 71 & 67 \\
\hline & & & & 75 & 22,9 & 0,51 & 70 & 67 \\
\hline & & & \multirow{3}{*}{21} & 50 & 24,6 & 0,42 & 69 & 64 \\
\hline & & 6 & & 60 & 22,8 & 0,39 & 68 & 65 \\
\hline & & & & 75 & - & 0,37 & 70 & 64 \\
\hline & & & & & Ort. & 0,46 & 70 & 66 \\
\hline & \multirow{10}{*}{19} & \multirow{3}{*}{4} & \multirow{3}{*}{60} & 50 & 27,8 & 0,49 & 69 & 62 \\
\hline & & & & 60 & 28,5 & 0,42 & 69 & 62 \\
\hline & & & & 75 & 30,2 & 0,43 & 69 & 61 \\
\hline & & & & 50 & 25,0 & 0,50 & 72 & 65 \\
\hline & & 5 & 28 & 60 & 26,6 & 0,48 & 70 & 63 \\
\hline & & & & 75 & 28,1 & 0,49 & 69 & 64 \\
\hline & & & & 50 & 29,4 & 0,54 & 69 & 62 \\
\hline & & 6 & 10 & 60 & 29,2 & 0,46 & 68 & 62 \\
\hline & & & & 75 & - & 0,35 & 68 & 61 \\
\hline & & & & & Ort. & 0,46 & 69 & 62 \\
\hline \multirow{20}{*}{400} & \multirow{9}{*}{12} & \multirow{3}{*}{4} & \multirow{3}{*}{67} & 50 & 25,3 & 0,31 & 70 & 62 \\
\hline & & & & 60 & 22,5 & 0,25 & 73 & 62 \\
\hline & & & & 75 & 22,3 & 0,32 & 70 & 60 \\
\hline & & \multirow{3}{*}{5} & \multirow{3}{*}{52} & 50 & 31,9 & 0,41 & 72 & 66 \\
\hline & & & & 60 & 32,4 & 0,37 & 71 & 66 \\
\hline & & & & 75 & 31,4 & 0,35 & 70 & 63 \\
\hline & & & \multirow{3}{*}{27} & 50 & 42,7 & 0,29 & 70 & 65 \\
\hline & & 6 & & 60 & 40,4 & 0,30 & 67 & 64 \\
\hline & & & & 75 & - & 0,31 & 65 & 63 \\
\hline & & & & & Ort. & 0,32 & 70 & 63 \\
\hline & \multirow{10}{*}{19} & \multirow{3}{*}{4} & \multirow{3}{*}{81} & 50 & 20,7 & 0,24 & 70 & 60 \\
\hline & & & & 60 & 19,1 & 0,20 & 69 & 60 \\
\hline & & & & 75 & 20,7 & 0,20 & 70 & 58 \\
\hline & & & & 50 & 34,7 & 0,27 & 70 & 64 \\
\hline & & 5 & 51 & 60 & 36,3 & 0,32 & 69 & 62 \\
\hline & & & & 75 & 34,7 & 0,33 & 70 & 64 \\
\hline & & & & 50 & 53,8 & 0,24 & 69 & 61 \\
\hline & & 6 & 28 & 60 & 52,3 & 0,25 & 70 & 63 \\
\hline & & & & 75 & 53,8 & 0,20 & 69 & 56 \\
\hline & & & & & Ort. & 0,25 & 69 & 61 \\
\hline
\end{tabular}



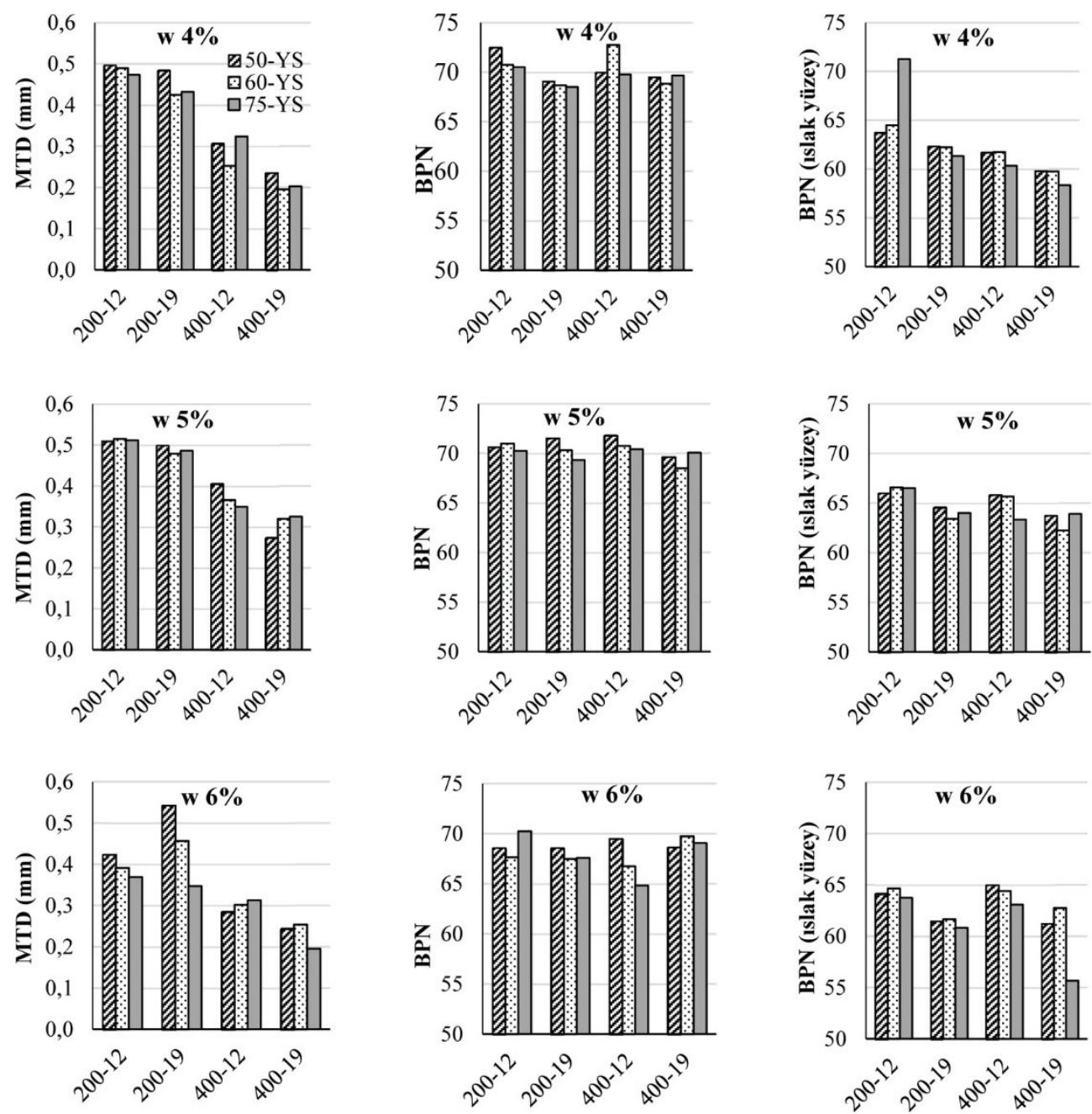

Şekil 8 - Her bir SSB karışımına ait ölçülen MTD ile BPN kuru ve ıslak yüzey değerleri

Bu sonuçlar, İngiliz İnşaat Mühendisleri Enstitüsü (ICE) tarafından hazırlanan Karayolları Tasarımı ve Yönetimi Kılavuzunda [24] SSB’lerin yüzey özelliklerin geliştirilmesinde çimento dozajının ve $\mathrm{D}_{\text {maks' }}$ 'n etkisinin vurgulanması açısından da önemli olmaktadır. İlgili kılavuzda SSB yüzey özelliklerinin iyileştirilmesi için karışım tasarımında çimento dozajı artışı ve daha düşük maksimum agrega dane büyüklüğü tavsiye edilmiştir. Ancak burada karışım parametrelerinin mikro ve makro doku yüzey özelliklerine etkisi ayrı ayrı incelenmemiştir. Bu çalışmada ise daha düşük $\mathrm{D}_{\text {maks' }}{ }^{\prime} 1$ karışımların MDT ve BPN değerleri açısından yol güvenliğine daha olumlu etki yaptığı gözlemlenirken, çimento dozajındaki artış özellikle makro yüzey dokusunda önemli düşüşe sebep olmuştur. Ancak bu çalışmadaki çimento artışının tipik kırsal yollarda kullanılan SSB karışım oranlamasının oldukça üzerinde olduğu unutulmamalıdır. 
SSB karışım parametrelerinin mikro ve makro doku özelliklerine etkilerinin daha iyi anlaşılabilmesi adına, Tablo 3'teki veriler kullanılarak istatistiksel analizler yapılmış ve Kısım 4.1 ve 4.2'de incelenmiştir. Ayrıca, SSB yüzey özellikleri ve kıvam ilişkisi de (Vebe süresi ve su oranı) incelenerek, Kısım 4.3'de detaylıca ele alınmıştır. Ek olarak, SSB karışımlarına ait basınç dayanımları ile yüzey özellikleri arasındaki ilişki de analiz edilmiştir. Ancak bir ilişki kurulamadığı için ayrı bir başlık altında bu çalışmada sunulmamıştır.

\subsection{SSB Karışım Parametrelerinin Makro Doku Özelliklerine Etkisi}

Bu çalışmada SSB karışım parametrelerinden çimento dozajı, su oranı ve $D_{\text {maks }}$ ile $S Y S$ yoğurma sayısının SSB makro doku derinliğine olan etkisinin incelenebilmesi için tek faktörlü varyans analizi (ANOVA) yapılmıştır (Tablo 4). IBM SPSS 22.0 [25] yazılımı kullanılarak gerçekleştirilen ANOVA istatiksel analizinde 108 numune sonucu kullanılmış, güven aralığı \%90 seçilerek anlamlılık değeri (p değeri) incelenmiş ve p değerinin 0,1 'den küçük olduğu $(p<0,1)$ parametrelerin sonuçlar üzerinde anlamlı bir etkisinin olduğu hipotezi kabul edilmiştir. Ayrıca p değerinin 0,01 (\%1) değerinden küçük olması ise ilgili bağımlı değişkenin bağımsız değişken üzerinde oldukça etkili olduğunu göstermektedir.

Tablo 4 - SSB karlşım parametrelerinin makro doku üzerinde etkisinin istatiksel analizi

\begin{tabular}{|c|c|c|c|c|c|c|}
\hline \multirow{2}{*}{$\begin{array}{c}\text { Bağımsız } \\
\text { değişkenler }\end{array}$} & \multicolumn{6}{|c|}{ ANOVA Çıktıları } \\
\hline & & $\mathrm{KT}$ & $\mathrm{Sd}$ & $\mathrm{KO}$ & $\mathrm{F}$ & P değeri \\
\hline \multirow{3}{*}{$\begin{array}{c}\text { Çimento } \\
\text { dozajı }\end{array}$} & G.İ & 0,821 & 1 & 0,821 & 176,820 & $\underline{0,000}$ \\
\hline & G.A & 0,492 & 106 & 0,005 & & \\
\hline & Toplam & 1,314 & 107 & & & \\
\hline \multirow{3}{*}{ Su oranı } & G.İ & 0,108 & 2 & 0,054 & 4,726 & $\underline{0,011}$ \\
\hline & G.A & 1,205 & 105 & 0,011 & & \\
\hline & Toplam & 1,314 & 107 & 0,054 & & \\
\hline \multirow{3}{*}{ D maks } & G.İ & 0,034 & 1 & 0,034 & 2,822 & $\underline{0,096}$ \\
\hline & G.A & 1,280 & 106 & 0,012 & & \\
\hline & Toplam & 1,314 & 107 & 0,034 & & \\
\hline \multirow{3}{*}{$\begin{array}{c}\text { SYS } \\
\text { yoğurma } \\
\text { sayısı }\end{array}$} & $\mathrm{G}, \dot{\mathrm{I}}$ & 0,024 & 2 & 0,012 & 0,992 & 0,374 \\
\hline & G.A & 1,289 & 105 & 0,012 & & \\
\hline & Toplam & 1,314 & 107 & 0,012 & & \\
\hline
\end{tabular}

Not: G.İ; Gruplar içi, G.A; Gruplar arası, KT; Kareler Toplamı, KO; Kareler Ortalaması, Sd; Serbestlik Derecesi; F; F istatistiği; P; anlamlılık değeri 
Bu çalışma için 108 numune üzerinden karışım parametrelerinin ve SYS yoğurma sayısının MTD etkileri üzerine gerçekleştirilen ANOVA istatiksel analiz çıktıları Tablo 4'te verilmiştir. Tablodaki her bir parametre için ayrı ayrı hesaplanan p değerleri incelendiğinde SSB karışım parametrelerinden çimento dozajının ve su oranının MTD üzerinde oldukça etkili $(p \leq 0,01)$ olduğu görülmektedir. Bu noktada SSB karışımlarında çimento ve su miktarının yalnızca mukavemet yönünden değil, aynı zamanda doku özellikleri bakımından da dikkat edilmesi gerektiği anlaşılmaktadır. Ayrıca karşımdaki $D_{\text {maks }}$ değerinin de \%90'lık güven aralığında $(\mathrm{p}<0,1)$ sonuçlara anlamlı bir etkisinin olduğu anlaşılmaktadır. Diğer taraftan SYS yoğurma sayısının doku derinliği üzerinde anlamlı bir etkisinin olmadığı ( $>0,1)$ hem ANOVA çıktısından anlaşılmakta hem de Şekil 8'de gözlemlenmektedir. Yapılan analizler sonucunda makro doku özelliklerinin çimento dozajı, su oranı ve $\mathrm{D}_{\text {maks'a }}$ bağlı olarak değiştiği görülmüştür. Yüksek hızlarda kaplama yüzeyinin drenajı makro dokuya bağlı olduğu için karışım parametrelerinin tasarım sırasında dikkatle seçilmesi gerekliliğini ortaya konmuştur.

\subsection{SSB Karışım Parametrelerinin Mikro Doku Özelliklerine Etkisi}

Aynı şekilde tek faktörlü ANOVA analizi Tablo 5'te görüldüğü üzere, bu kez SSB karışım parametrelerinin mikro doku özellikleri üzerinde etkilerinin anlaşılabilmesi için uygulanmıştır.

Tablo 5 - SSB karışım özelliklerinin mikro doku üzerinde etkisinin istatiksel analizi (a) $B P N-k u r u$ yüzey (b) BPN-ıslak yüzey değerleri

(a) BPN-Kuru Yüzey

\begin{tabular}{ccccccc}
\hline \multirow{2}{*}{$\begin{array}{c}\text { Bağımsız } \\
\text { değişkenler }\end{array}$} & \multicolumn{7}{c}{ ANOVA Çıktıları } \\
\cline { 2 - 7 } Çimento & G.İ & 0,775 & 1 & 0,775 & 0,215 & $\mathbf{0 , 6 4 4}$ \\
& G.A & 382,862 & 106 & 3,612 & & \\
dozajı & Toplam & 383,637 & 107 & 0,775 & & \\
\hline \multirow{2}{*}{ Su oranı } & G.İ & 95,747 & 2 & 47,874 & 17,461 & $\underline{\mathbf{0 , 0 0 0}}$ \\
& G.A & 287,890 & 105 & 2,742 & & \\
& Toplam & 383,637 & 107 & & & \\
D.maks & G.İ & 16,062 & 1 & 16,062 & 4,632 & $\underline{\mathbf{0 , 0 3 4}}$ \\
& G.A & 367,575 & 106 & 3,468 & & \\
Soplam & 383,637 & 107 & & & \\
yoğurma & G.İ & 12,899 & 2 & 6,450 & 1,827 & $\mathbf{0 , 1 6 6}$ \\
sayısı & G.A & 370,737 & 105 & 3,531 & & \\
\hline & Toplam & 383,637 & 107 & & & \\
\hline
\end{tabular}


Tablo 5 - SSB karışım özelliklerinin mikro doku üzerinde etkisinin istatiksel analizi (a) $B P N-k u r u$ yüzey (b) BPN-ıslak yüzey değerleri (devam)

\section{(b) BPN-Islak Yüzey}

\begin{tabular}{|c|c|c|c|c|c|c|}
\hline \multirow{2}{*}{$\begin{array}{c}\text { Bağımsız } \\
\text { değişkenler }\end{array}$} & \multicolumn{6}{|c|}{ ANOVA Çıktıları } \\
\hline & & KT & $\mathrm{Sd}$ & $\mathrm{KO}$ & $\mathrm{F}$ & P değer \\
\hline \multirow{3}{*}{$\begin{array}{c}\text { Çimento } \\
\text { dozajı }\end{array}$} & G.İ & 54,898 & 1 & 54,898 & 8,469 & $\underline{0,004}$ \\
\hline & G.A & 687,144 & 106 & 6,482 & & \\
\hline & Toplam & 742,042 & 107 & & & \\
\hline \multirow{3}{*}{ Su oranı } & G.İ & 186,691 & 2 & 93,345 & 17,649 & $\underline{0,000}$ \\
\hline & G.A & 555,351 & 105 & 5,289 & & \\
\hline & Toplam & 742,042 & 107 & & & \\
\hline \multirow{3}{*}{ D maks } & G.I & 162,558 & 1 & 162,558 & 29,735 & $\underline{0,000}$ \\
\hline & G.A & 579,484 & 106 & 5,467 & & \\
\hline & Toplam & 742,042 & 107 & & & \\
\hline \multirow{3}{*}{$\begin{array}{c}\text { SYS } \\
\text { yoğurma } \\
\text { sayısı }\end{array}$} & G.İ & 43,337 & 2 & 21,668 & 3,256 & $\underline{0,042}$ \\
\hline & G.A & 698,705 & 105 & 6,654 & & \\
\hline & Toplam & 742,042 & 107 & & & \\
\hline
\end{tabular}

Not: G.İ; Gruplar içi, G.A; Gruplar arası, KT; Kareler Toplamı, KO; Kareler Ortalaması, Sd; Serbestlik Derecesi; F; F istatistiği; P; anlamlılık değeri

Mikro doku, lastikle yol arasında kuru temas açısından önemli olduğu için, taşıtların yol tutuşu üzerinde çok önemli etkisi bulunmaktadır. Bu sebeple Tablo 5 'te görüldüğü üzere hem kuru hem de ıslak BPN değerlerinin karışım parametrelerinden nasıl etkilendiği ayrı ayrı analiz edilmiş̧ir. Islak BPN sonuçlarına tüm parametrelerin $(p<0,05)$ etkili olduğu görülürken, özellikle çimento dozajı, su oranı ve $\mathrm{D}_{\text {maks }}$ parametrelerinin 1 slak BPN değeri üzerinde etkileri $(p<0,01)$ oldukça fazla olmuştur. Diğer taraftan kuru BPN değerleri için bu durum geçerli olmamaktadır. Bu sonuçlar ışığında kuru BPN üzerinde su oranı ve $\mathrm{D}_{\text {maks }}$ etkili $(\mathrm{p}<0,05)$ olurken, çimento dozajının ve SYS yoğurma sayısının etkisi görülememiştir. Ancak uygulamada ıslak BPN değerinin daha kritik olduğu göz önüne alındığında [26, 27], çimento dozajının etkisinin de sonuçlarda oldukça önemli olduğu sonucuna varmak yanlış olmayacaktır.

Bir önceki bölümde de tartışıldığı üzere SSB kaplamalarının hem makro hem de mikro doku özellikleri istatiksel olarak karışım parametrelerinden çimento dozajı, su oranı ve $D_{\text {maks }}$ 'n değişiminden etkilenmektedir. 


\subsection{SSB Yüzey Özellikleri ve Kıvam İlişkisi}

Yüzey özelliklerini belirleyen MTD ve BPN değerleri ile SSB Vebe kıvam süresi ilişkisi incelendiğinde, ilk olarak Şekil 9'dan da görüldüğü üzere parabolik ilişki göze çarpmaktadır. 0,42 mm MTD değeri için 20-40 sn'lik Vebe süreleri optimum sonuç verdiği görülürken, 65 BPN (ıslak) için bu süre 30-50 sn'lik Vebe süresinin bandına kaydığı görülmektedir.
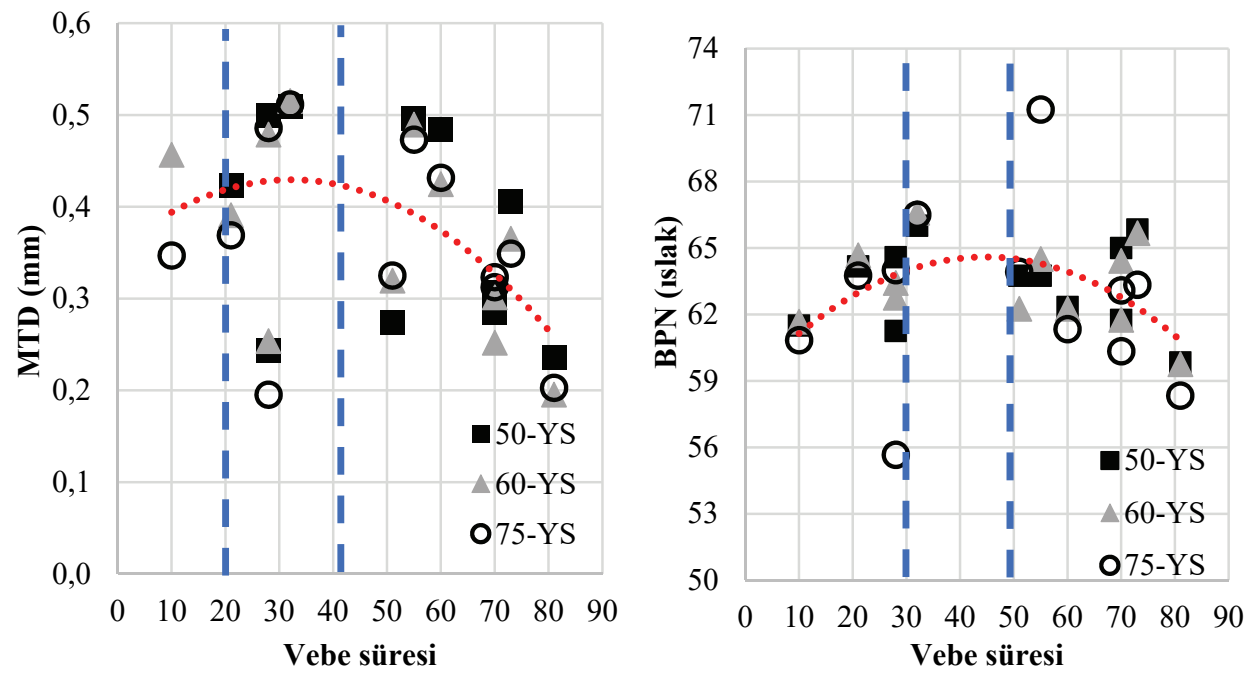

Şekil 9 - Vebe kıvam süresi MTD ve BPN ilişkisi

Bu sonuçlar, literatürde Chhorn vd. (2017) [3] tarafından yapılan BPN değeri ile Vebe süresi ilişkisinin araştırıldığı ve aralarında parabolik bir ilişki gözlemlenerek, 55 sn'lik Vebe süresi için 65 BPN değeri ile optimum değerin yakalandığ Diğer taraftan bu çalışmada ölçümü yapılan SSB yolun gerçek saha şartlarında asfalt sericiler ile yerleştirilerek, titreşimli çift tamburlu silindirler ve lastik tekerlekle sıkıştırıldığ1 düşünülürse o çalışma ile sahayı temsil etmesi açısından laboratuvar koşullarında SYP ile üretilen SSB'ler üzerinde ölçümler yapılarak gerçekleştirilen bu çalışmanın, birbirine oldukça yakın sonuçlar vermesi aynı zamanda SYP'nin de SSB üretiminde laboratuvarda gerçek saha koşullarını yakalaması açısından ne derece de başarılı olduğunu göstermektedir. Bu çalışmada makro ve mikro doku yüzeyi beraber düşünülerek, saha uygulaması için uygun

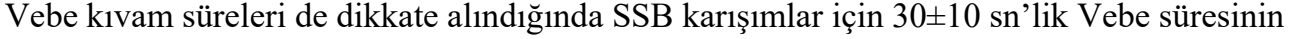
uygun olacağı sonucuna varılmıştır [7, 28].

Vebe süresi ile MTD ve BPN değerlerinde görülen benzer parabolik ilişki beklenildiği üzere karışımın ihtiva ettiği su oranı ile de Şekil 10'da gözlemlenmiştir. Şekil 10'da görüldüğü üzere maksimum MTD değerleri numune sıkıştırılmasından (yoğurma sayısı) bağımsız olarak optimum su ihtiva eden karışım numunelerinden elde edilmiştir. Optimum su oranı belirlenmesinin detayları Şengün vd. (2019)[17] mevcuttur. Sadece 50 yoğurma sayısı için bir karışımda bu parabolik ilişki yakalanamamıştır. Diğer tüm karışımlar için yoğurma 
sayısından, çimento dozajından ve $\mathrm{D}_{\text {maks }}$ 'dan bağımsız olarak $\% 5$ 'lik bir su oranında optimum yüzey derinliğine ulaşıldığı görülmektedir.

Aynı durum kuru ve 1slak yüzeyler için BPN değerlerinin su oranı ilişkisinde de görülmekte olup, Şekil 11'de görüldüğü üzere tüm karışımlar için \%5'lik bir su oranında optimum kuru ve ıslak yüzeyler için BPN değerleri elde edilmiştir. Yapılan bu analizler ayrıca, SSB karışım tasarımda optimum su ihtiva oranının doğru belirlenmesinin yol güvenliği açısından da ne kadar önemli olduğunu ortaya koymuştur.
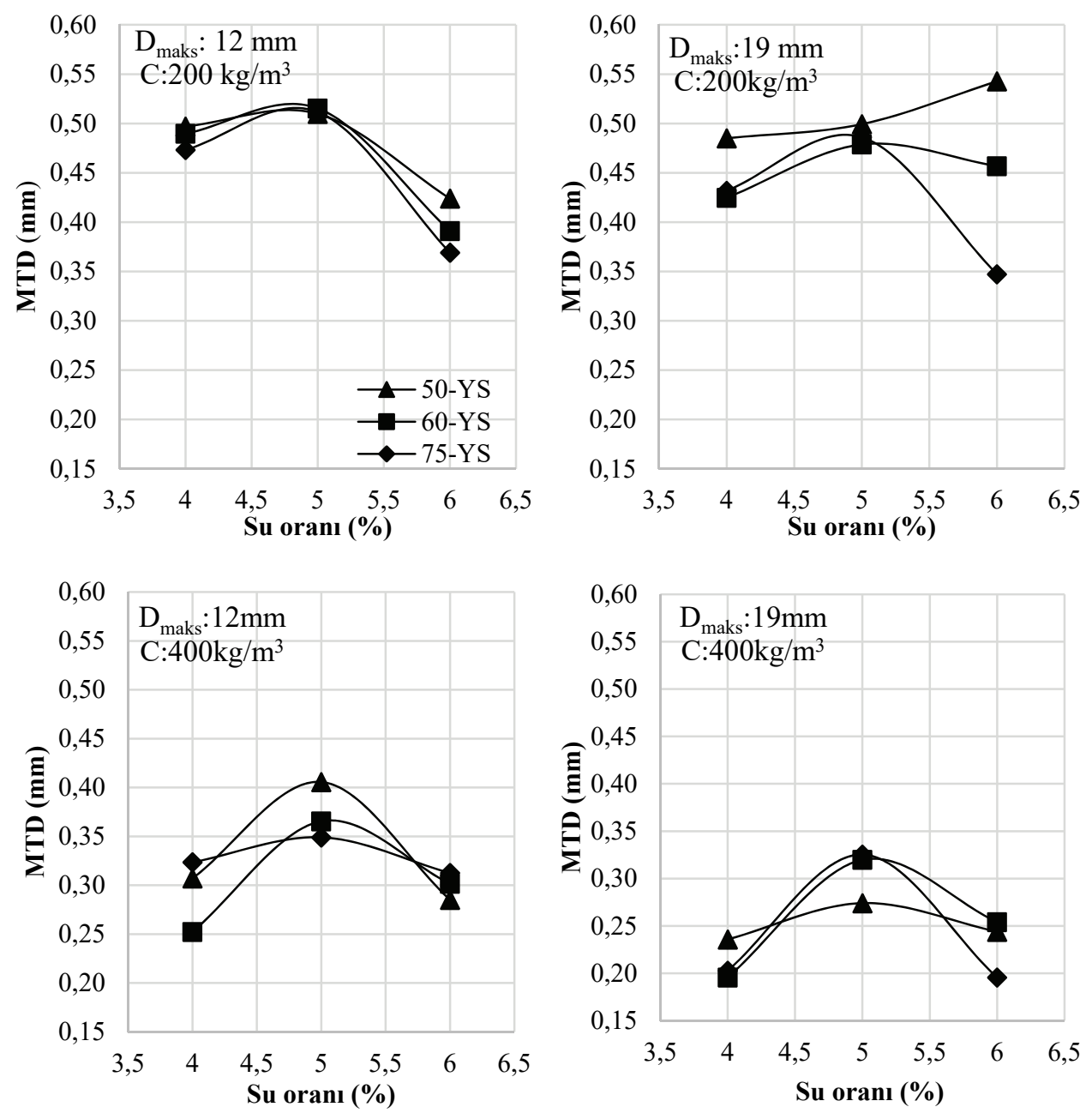

Şekil 10 - MTD ile SSB karışımı su oranı ilişkisi. 

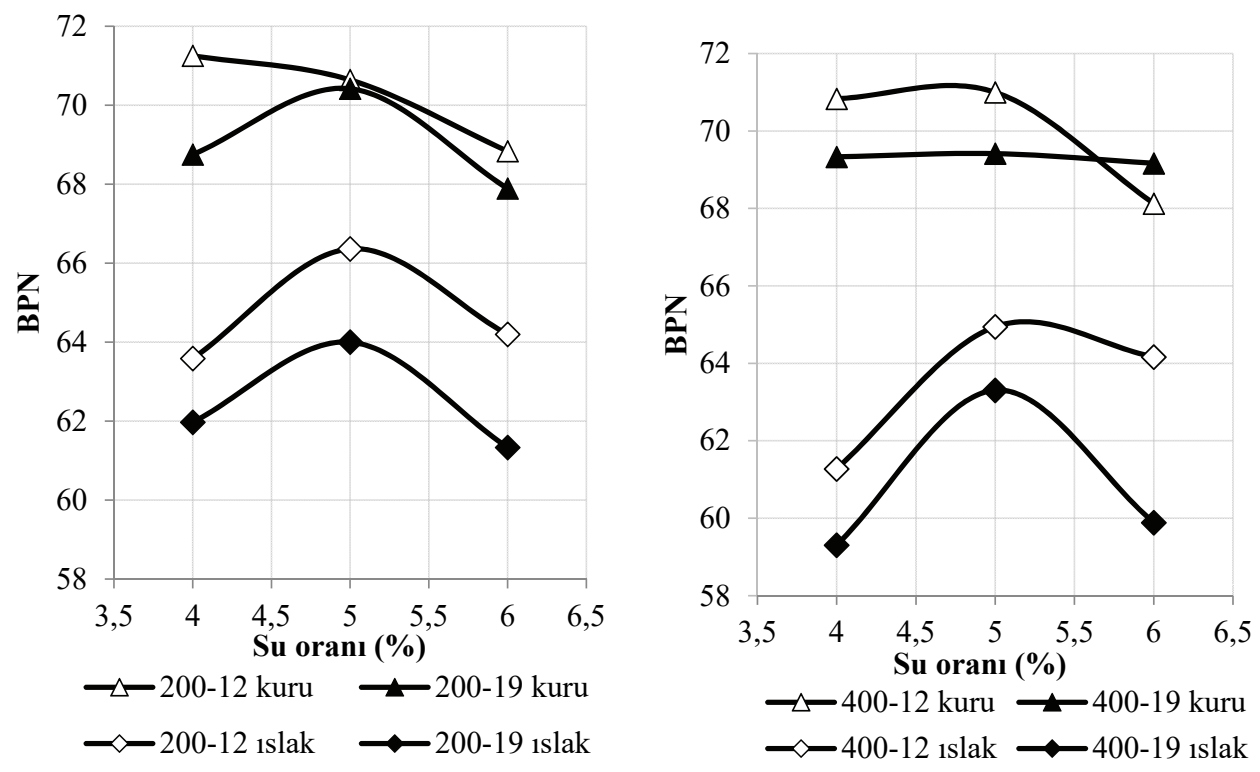

Şekil 11 - Kuru ve ıslak yüzey BPN değeri (60 yoğurma sayısı için) SSB karışımı su oranı ilişkisi

\section{SONUÇLAR VE TARTIŞMA}

SSB kaplamaların makro ve mikro yüzey özelliklerinin belirlenmesi ve ayrıca karışım parametrelerinin bu özelliklere etkilerinin incelenebilmesi adına gerçekleştirilen bu çalışmada; iki farklı çimento dozajı $\left(200-400 \mathrm{~kg} / \mathrm{m}^{3}\right)$, iki farklı agrega gradasyonu ( $D_{\text {maks }} 12-$ $19 \mathrm{~mm}$ ) ve üç farklı su oranı (\%4-\%5-\%6) ile hazırlanan 12 farklı karışım ele alınmıştır. Her bir SSB karışımı 50, 60 ve 75 olmak üzere üç farklı yoğurma sayısında saha sıkıştırma şartlarını laboratuvar koşullarında temsil etmesi adına Superpave yoğurmalı presi ile sıkıştırılmış ve üretilen üçer adet numuneler üzerinde kaplama yüzey derinliğinin bulunabilmesi için kum yama testi, mikro ölçekli kayma potansiyelinin belirlenebilmesi adına da İngiliz pandül testi uygulanmıştır. Elde edilen sonuçlar üzerinden ayrıca tek faktörlü ANOVA analizleri yapılarak karışım parametrelerinin SSB yüzey dokusuna etkileri incelenmiştir.

Bulgular kısaca aşağıdaki gibi özetlenebilir;

- 200 ve 400 dozajlı karışımlar için ortalama yüzey derinliği sırasıyla $0,46 \mathrm{~mm}$ ve $0,29 \mathrm{~mm}$ elde edilmiştir. Değerler KGM beton yollar için belirlenen değerlerin altında kalsa da 200 dozajlı karışımlar şartname sınır değerlerine çok yakındır. Bu da şehir içi ve köy yollarında kullanımı giderek artan SSB kaplamaların yol güvenliği açısından büyük önem arz etmektedir.

- Tüm SSB karışımları için BPN değerleri kuru yüzeyde 70, sslak yüzeyde ise 200 dozaj için 64, 400 dozaj için 62 civarı gözlemlenmiştir. Bu BPN değerleri ile SSB 
kaplamalar çok düşük kayma potansiyeline sahip kaplama sınıfına girmektedir. Bu sonuç yol güvenliği açısından, uygulamada ilave tedbirlerin (hız limitlerinin düşürülmesi gibi) alınması gerekliliğini öne çıkarmaktadır.

- Karışımlardaki çimento dozajı artışı, SSB kaplamaların makro dokusunu oldukça etkilemiş ve ortalama yüzey derinliğinde önemli derecede düşüşe neden olmuştur. Agrega boyut etkisi ise yüksek dozajlı karışımlarda boyut artışı ile düşüşe sebep olmuştur.

- $\quad$ BPN değerleri için çimento dozajının etkisi ıslak yüzey ölçümlerinde gözlemlenmiş ve dozajda yükseliş ile BPN'de düşüş yaşanmıştır.

- $\quad$ SSB karışım kıvamı ile yüzey özellikleri arasında parabolik bir ilişki saptanmış olup SSB karışımlarına ait $30 \pm 10$ sn'lik Vebe süresi ve $\% 5^{\prime}$ lik su oranında optimum makro ve mikro değerler elde edilmiştir.

SSB kaplamaların kullanımında büyük bir potansiyel mevcut olmakla birlikte özellikle yol güvenliği açısından yüzey özelliklerinin belirlenerek kontrol altına alınması ve gerektiğinde uygulamada ilave tedbirlerin alınması gerekmektedir. Yukarıda özetlenen bulgulardan da görüldügüü üzere, karışım parametrelerinin (çimento dozajı, su oranı ve agrega boyutu) SSB yüzey özelliklerinde istatiksel olarak etkili olduğu görülmüş̧ür. Dolayısıyla, SSB karışım parametreleri seçiminde, üstyapı mukavemeti ve dayanıklılığının yanısıra yol güvenliğinin de gözönüne alınması ve SSB kaplama üretim mevzuatına hem maliyeti düşük olan hem de hızlı yapılan kum yama testi ile İngiliz pandül testlerinin de eklenmesi önerilmektedir.

\section{Semboller}

$\begin{array}{ll}\text { ABD } & \text { Amerika Birleşik Devletleri } \\ \text { ACI } & \text { Amerikan Beton Enstitüsü } \\ \text { ACPA } & \text { Amerikan Beton Yollar Birliği } \\ \text { ANOVA } & \text { Varyans Analizi } \\ \text { BPT } & \text { İngiliz Pandül Testi } \\ \text { BPN } & \text { İngiliz Pandül Sayısı } \\ \text { BSK } & \text { Bitümlü Sıcak Kaplama } \\ \text { C } & \text { Çimento Dozajı (kg/m³) } \\ \text { D } & \text { Agrega boyutu } \\ \text { D } m a k s & \text { Maksimum Agrega Dane Boyutu } \\ \text { F } & \text { F istatistiği } \\ \text { GA } & \text { Gruplar arası (ANOVA analizinde) } \\ \text { Gİ } & \text { Gruplar içi (ANOVA analizinde) } \\ \text { KGM } & \text { Karayolları Genel Müdürlüğü }\end{array}$




$\begin{array}{ll}\text { KO } & \text { Kareler Ortalaması } \\ \text { KT } & \text { Kareler Toplamı } \\ \text { MTD } & \text { Ortalama Doku Derinliği } \\ \text { Sd } & \text { Serbestlik Derecesi } \\ \text { s/ç } & \text { Su Çimento Oranı } \\ \text { p } & \text { Anlamlılık Değeri } \\ \text { SSB } & \text { Silindirle Sıkıştırılmış Beton } \\ \text { SYP } & \text { Superpave Yoğurmalı Pres } \\ \text { YS } & \text { Yoğurma Sayısı }\end{array}$

\section{Teşekkür}

Bu çalışma, Türkiye Bilimsel ve Teknolojik Araştırma Kurumu (TUBİTAK) tarafından finanse edilen SSB kaplamalar (Proje No: 116M523) üzerine gerçekleştirilen araştırma projesi kapsamında üretilen numuneler kullanılarak gerçekleştirilmiştir. Yazarlar, mezun Mehmet Ali Aykutlu'ya ve Emine Bilge Tan’a çalışma sırasında yardımlarından dolayı teşekkür ederler.

\section{Kaynaklar}

[1] Harrington D., Abdo F., Adaska W., Hazaree C.V.,Ceylan H., and Bektas F., "Guide for roller-compacted concrete pavements," 2010.

[2] Uz E.V, Gökalp İ., Epsileli E., Tepe M., "Karayolları Teknik Şartnamesinde (KTŞ) Yer Alan Pürüzlendirme Uygulaması ve bu Uygulamada Endüstriyel Atıkların Kullanılabilirliği,” 3. Karayolu Ulusal Kongresi, Ankara, 25-27 Kasım 2014.

[3] Chhorn C., Hong S.J., Lee SW., "A study on performance of roller-compacted concrete for pavement," Constr. Build. Mater.,153, 535-543, 2017.

[4] Mohammed B.S., Adamu M., "Mechanical performance of roller compacted concrete pavement containing crumb rubber and nano silica," Constr. Build. Mater.,159,234$251,2018$.

[5] Tavakoli D., Dehkordi R.S., Divandari H., Brito J., "Properties of roller-compacted concrete pavement containing waste aggregates and nano SiO2," Constr. Build. Mater., 249,118747, 2020.

[6] Algin Z., Gerginci S., "Freeze-thaw resistance and water permeability properties of roller compacted concrete produced with macro synthetic fibre," Constr. Build. Mater., 234,117382, 2020.

[7] ACI 327R-14, "Guide to roller-compacted concrete pavements," 2015. 
[8] ASTM E670-09, "Standard Test Method for Testing Side Force Friction on Paved Surfaces Using the Mu-Meter," ASTM International, West Conshohocken, PA, 2015.

[9] ASTM C33M-18, "Standard Specification for Concrete Aggregates," West Conshohocken, PA, 2018.

[10] ASTM C136M-14, "Standard Test Method for Sieve Analysis of Fine and Coarse Aggregates," West Conshohocken, PA, 2014.

[11] ASTM C127-15, "Standard Test Method for Relative Density (Specific Gravity) and Absorption of Coarse Aggregate," West Conshohocken, PA, 2015.

[12] ASTM C128-15, "Standard Test Method for Relative Density (Specific Gravity) and Absorption of Fine Aggregate," West Conshohocken, PA, 2015.

[13] ASTM C125-19, "Standard Terminology Relating to Concrete and Concrete Aggregates," West Conshohocken, PA, 2019.

[14] ACPA (American Concrete Pavement Association), "Roller-Compacted Concrete Guide Specification,” 2014.

[15] Karayolları Genel Müdürlüğü, "Karayolu Teknik Şartnamesi (Yol Üstyapısı, Sanat Yapıları, Köprü ve Tüneller, Üstyapı ve Çeşitli İşler),” 2013.

[16] ASTM C1170, "Standard Test Method for Determining Consistency and Density of Roller-Compacted Concrete Using a Vibrating Table," West Conshohocken, PA, 2014.

[17] Şengün E., Alam B., Shabani R., Yaman I.O., "The effects of compaction methods and mix parameters on the properties of roller compacted concrete mixtures," Constr. Build. Mater.,228, 2019.

[18] ASTM C1800, "Standard Test Method for Determining Density of Roller-Compacted Concrete Specimens Using the Gyratory Compactor,” 2016.

[19] ASTM E965-15, "Standard Test Method for Measuring Pavement Macrotexture Depth Using a Volumetric Technique," West Conshohocken, PA, 2019.

[20] Kaçmaz B., Topal A., Şengöz B., Tanyel S., "Farklı tip esnek kaplamaların yol yüzey özelliklerinin arazi ölçümleriyle değerlendirilmesi," Tek. Dergi, 26(3),7115-7137, 2015.

[21] Karayolları Genel Müdürlüğ̈ “Beton Yollar Teknik Şartnamesi,” KGM ARGE Daire Başkanlığı1, Ankara, Türkiye, 2016.

[22] ASTM E303-93, "Standard Test Method for Measuring Surface Frictional Properties Using the British Pendulum Tester," West Conshohocken, PA, 2018.

[23] Yıldız K., "Şehir İçi Asfalt Kaplamaların Kayma Potansiyelinin Değerlendirilmesi-Bir Durum Çalışması,” Politek. Derg., 21(2) ,513-518, 2018.

[24] Donegan, J. P. (2011). Roller compacted concrete, chapter 48, ICE Manual of Highway Design and Management. Institution of Civil Engineers.

[25] IBM Corporation, “IBM SPSS statistics for windows,” Version 22.0, 2013. 
[26] Meegoda J. N., Gao S., "Evaluation of pavement skid resistance using high speed texture measurement," J. Traffic Transp. Eng., 2(6), 382-390, 2015.

[27] D’Apuzzo M., Evangelisti A., Nicolosi V., "An exploratory step for a general unified approach to labelling of road surface and tyre wet friction," Accid. Anal. Prev., $138,105462,2020$.

[28] Şengün E., "Effects of mixture design parameters and compaction methods on the properties of roller compacted concrete pavements, $\mathrm{PhD}$ Thesis," Middle East Technical University, 2019. 